\title{
Behaviors of Concrete with Recycled Clay Brick as Fine Aggregate
}

\author{
Wencui Yang, Xiaoping Cai and Duojie Jiangjiu
}

School of Transportation Science and Engineering, Harbin Institute of Technology, 73 Huanghe Road, Nangang District, 150090, Harbin, China, yangwencui@hit.edu.cn, caixiaoping@hit.edu.cn

\begin{abstract}
Massive waste materials were produced by the construction and demolition industry every year. In residential constructions, clay bricks are a dominant material and they account for a large proportion of construction and demolition waste. Using crushed bricks in cement concrete is an effective way to preserve natural aggregate and to reduce construction and demolition waste. The mechanical properties, the permeability and the carbonation resistance of concrete with recycled clay brick as fine aggregate were studied in this paper. The results showed that the compressive strength, the flexural strength and the impermeability of concrete decreased with the increasing of the replacement percent of recycled clay brick. However, the permeability of concrete with the water to cement ratio of 0.35 was still at the "Low" level when the replacement percent was less than or equal to $75 \%$. The carbonation resistance of concrete using recycled clay bricks as fine aggregate was degraded.
\end{abstract}

Keywords: Construction and Demolition Waste, Fine Recycled Aggregate, Clay Brick, Durability.

\section{Introduction}

Vast amounts of waste materials are produced by the construction and demolition industry every year. The volume of these materials has reached an unacceptable level from an environmental, economic and social point of view (Vieira et al., 2016). In residential construction, clay bricks are a dominant material, so they account for a large proportion of construction and demolition waste (Crowther, 2000; Formoso et al., 2002). Since concrete is the most widely used construction materials in the world, using crushed bricks in concrete is an effective way to preserve natural aggregate and to reduce construction and demolition waste.

Several studies have been conducted to investigate the potential of using clay brick as aggregates. Poon and Chan (2006) investigated the possibility of using crushed clay brick as aggregates in sub-base materials. A study by Lan Zong showed the permeability of water, air and chloride ions increased when recycled coarse aggregates were used. Additionally, the recycled concrete containing clay brick waste had increased porosity and exhibited a loose paste matrix (Zong et al., 2014). Schackow used a powdered $(<45 \mu \mathrm{m})$ fired clay brick clean waste to replace Portland cement, and 28 and 90 days-compressive strength, water absorption, apparent porosity, absorption by capillarity, chloride retention, carbonation depth and sulphate resistance were evaluated. According to the results, they suggested that a moderate clay brick clean waste addition (up to $10 \mathrm{wt} . \%$ ) is desirable if a comparable workability is desired (Schackow et al., 2015). Adamson's research (2015) showed that the natural coarse aggregates can be replaced by crushed bricks, without significant change in the durability of concrete when the steel is not present. However, when concrete is reinforced with steel, replacing natural aggregates with crushed brick is not recommended. Bektas's study (2009) 
indicated that as the brick replacement level increased, the mortar flow ability reduced. The $10 \%$ and $20 \%$ brick replacements had no negative effect on the mortar compressive strength and very limited effect on the mortar shrinkage.

This paper reports a study with the aim to investigate the mechanical properties and durability of concrete with recycled clay brick as fine aggregate. By conducting a sort of laboratory experiments, the compressive strength, flexural strength, permeability and carbonation resistance of concrete with recycled clay brick were studied.

\section{Experimental Program}

\subsection{Materials}

Ordinary Portland Cement (P.O 42.5) was used in accordance with China National Standard GB/175-2009, and Table 1 summarized its properties.

Table 1. Chemical and physical properties of cement.

\begin{tabular}{cccccc}
\hline $\begin{array}{c}\text { Initial setting time } \\
(\text { min })\end{array}$ & $\begin{array}{c}\text { Final setting time } \\
(\text { min })\end{array}$ & \multicolumn{2}{c}{$\begin{array}{c}\text { Tensile strength } \\
(\mathrm{MPa})\end{array}$} & \multicolumn{2}{c}{$\begin{array}{c}\text { Compressive strength } \\
(\mathrm{MPa})\end{array}$} \\
\cline { 2 - 6 } & 250 & $3 \mathrm{~d}$ & $28 \mathrm{~d}$ & $3 \mathrm{~d}$ & $28 \mathrm{~d}$ \\
\hline 190 & 4.2 & 7.1 & 22.9 & 43.8 \\
\hline
\end{tabular}

Natural river sand

Crushed limestone was

in Table 2. Recycled c

brick was controlled as t.

Table 3 and Table 4 sh
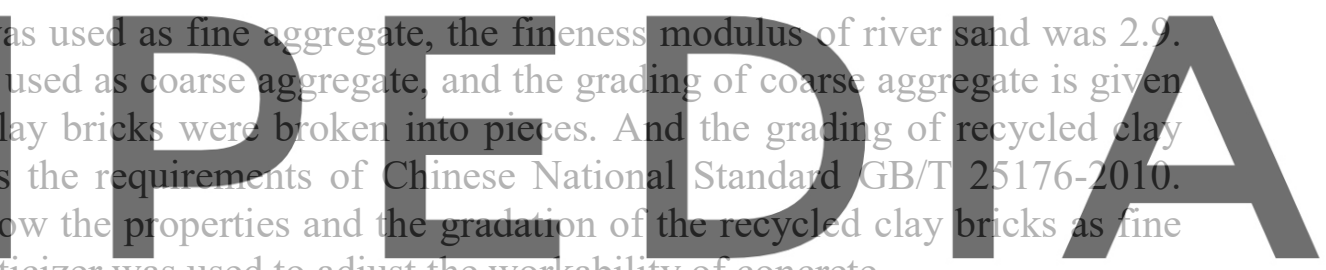

aggregate. A super plasticizer was used to adjust the workability of concrete.

Register for free at https//www.scipaed ba.comatogdodandoagdtata. version without the watermark

\begin{tabular}{ccccc}
\hline Sieve pore size $(\mathrm{mm})$ & $19.0-26.5$ & $16.0-19.0$ & $9.5-16.0$ & $4.75-9.5$ \\
\hline Percentage $(\%)$ & 25 & 25 & 35 & 15 \\
\hline
\end{tabular}

Table 3. The properties of recycled clay brick.

\begin{tabular}{ccc}
\hline Apparent density $\left(\mathrm{g} / \mathrm{cm}^{3}\right)$ & Packing density $\left(\mathrm{kg} / \mathrm{m}^{3}\right)$ & Close packing density $\left(\mathrm{kg} / \mathrm{m}^{3}\right)$ \\
\hline 2.34 & 899 & 994 \\
\hline
\end{tabular}

Table 4. The grading of recycled clay brick as fine aggregate.

\begin{tabular}{cccccccc}
\hline Sieve pore size $(\mathrm{mm})$ & 4.75 & 2.35 & 1.18 & 0.6 & 0.3 & 0.15 & $<0.15$ \\
\hline Percentage $(\%)$ & 2 & 7 & 10 & 30 & 36 & 13 & 2 \\
\hline
\end{tabular}

\subsection{Mix Proportions and Sample Preparation}

The proportions of reference concrete with the water to cement ratio of 0.35 and 0.47 are given in Table 5. The recycled clay brick was introduced as volume percentage of the 
concrete fine aggregate, and four levels of replacement, $25 \%, 50 \%, 75 \%$ and $100 \%$, were investigated.

Due to the high water absorption of recycled clay brick, it is suggested to soak the brick aggregate in water prior to adding to concrete [Khalaf, 2005; Khalaf, 2006; Cachim, 2009]. Therefore, this procedure was adopted in this work for recycled clay brick. The recycled clay brick aggregate was soaked in water for $24 \mathrm{~h}$ and added to concrete mixture in a saturated condition.

Table 5. Mixture proportions of reference concrete $\left(\mathrm{kg} / \mathrm{m}^{3}\right)$.

\begin{tabular}{cccccc}
\hline$W / C$ & Water & Cement & Sand & Gravel & Super plasticizer \\
\hline 0.35 & 175 & 500 & 629 & 1106 & 4.5 \\
\hline 0.47 & 175 & 372 & 702 & 1151 & 4.5 \\
\hline
\end{tabular}

2.3 Methods

\subsubsection{Mechanical properties}

The compressive strength and flexural strength of concrete were tested at $28 \mathrm{~d}$ age. The compressive strength specimens with the size of $100 \mathrm{~mm} \times 100 \mathrm{~mm} \times 100 \mathrm{~mm}$ and the flexural strength specimens with the size of $100 \mathrm{~mm} \times 100 \mathrm{~mm} \times 400 \mathrm{~mm}$ were tested in accordance with the Chinese standard GB/T 50081-2002.
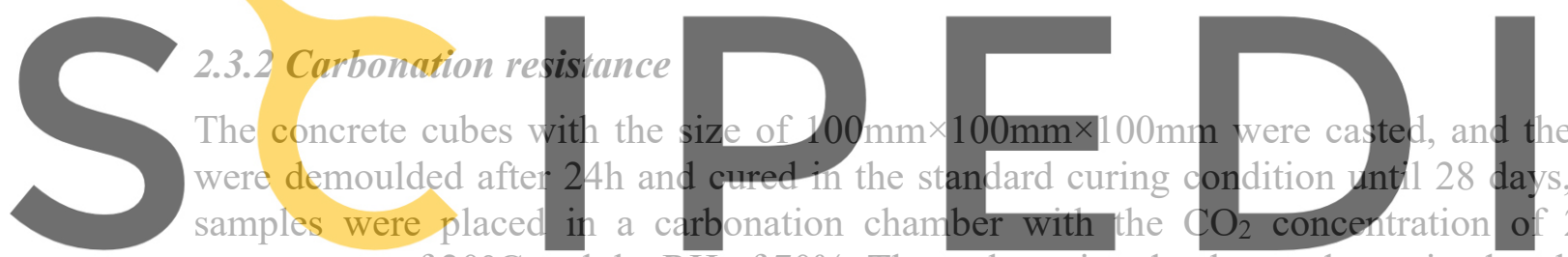

temperature of $20^{\circ} \mathrm{C}$ and the $\mathrm{RH}$ of $70 \%$. The carbonation depth was determined at the start of

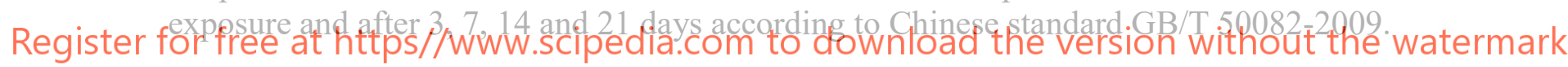

\subsubsection{Permeability}

The permeability of concrete was measured at $28 \mathrm{~d}$ age according to the Chinese standard GB/T 50082-2009, and the size of specimen was $\varphi 100 \mathrm{~mm} \times 50 \mathrm{~mm}$.

\section{Test Results and Discussion}

\subsection{Mechanical Properties}

Table 6 demonstrates the compressive strength and the flexural strength obtained from the concrete samples with different replacement of recycled clay bricks. Each data represents the average of three samples. It was observed that with the increasing of recycled clay brick content, both the compressive strength and the flexural strength decreased. When the water to cement ratio was 0.35 , the compressive strength loss of approximately $20 \%$ at 28 days was observed in concrete produced with $25 \%$ recycled clay brick replacement ratio. The reduction in compressive strength was observed more significantly in concrete with $75 \%$ or more replacement ratio as it decreased over $30 \%$. The compressive strength of concerte with the 
water to cement ratio of 0.47 showed the similar change, and the decrease of compressive strength was more than $30 \%$ when $25 \%$ recycled clay brick was added. It was shown the replacement of recycled clay bricks had more influence on the concrete with higher water to cement ratio.

Table 6. Mechanical properties of concrete (28d).

\begin{tabular}{cccc}
\hline \multirow{3}{*}{$W / C$} & $\begin{array}{c}\text { Replacement percentage } \\
(\%)\end{array}$ & $\begin{array}{c}\text { Compressive strength } \\
(\mathrm{MPa})\end{array}$ & $\begin{array}{c}\text { Flexural strength } \\
(\mathrm{MPa})\end{array}$ \\
\hline \multirow{5}{*}{0.35} & 0 & 51.8 & 6.0 \\
\cline { 2 - 4 } & 25 & 42.3 & 4.8 \\
\cline { 2 - 4 } & 50 & 41.5 & 4.1 \\
\cline { 2 - 4 } & 75 & 35.2 & 3.8 \\
\hline & 100 & 32.3 & 3.6 \\
\hline & 0 & 48.3 & 4.5 \\
\hline & 25 & 33.2 & 4.1 \\
\hline & 50 & 31.2 & 3.7 \\
& 75 & 26.8 & 3.4 \\
\hline
\end{tabular}

\subsection{Permeability}

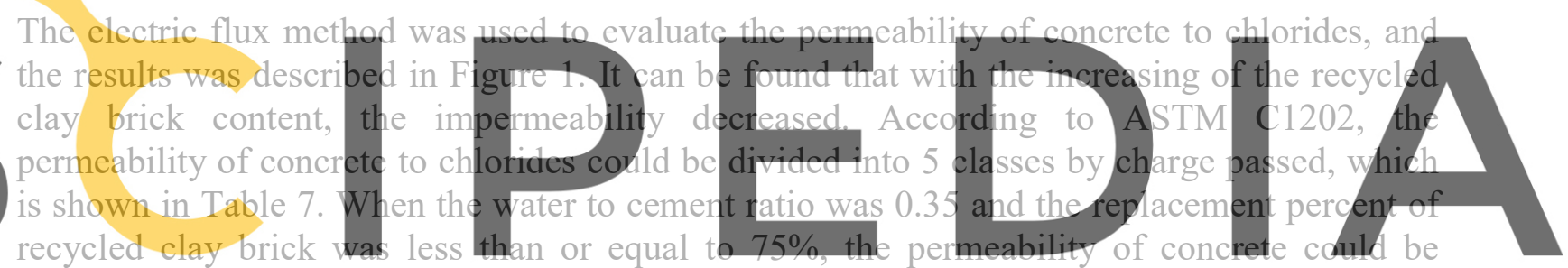

evaluated as "Low". When the water to cement ratio was 0.47 and the replacement percent of

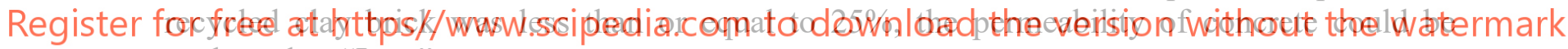
evaluated as "Low".

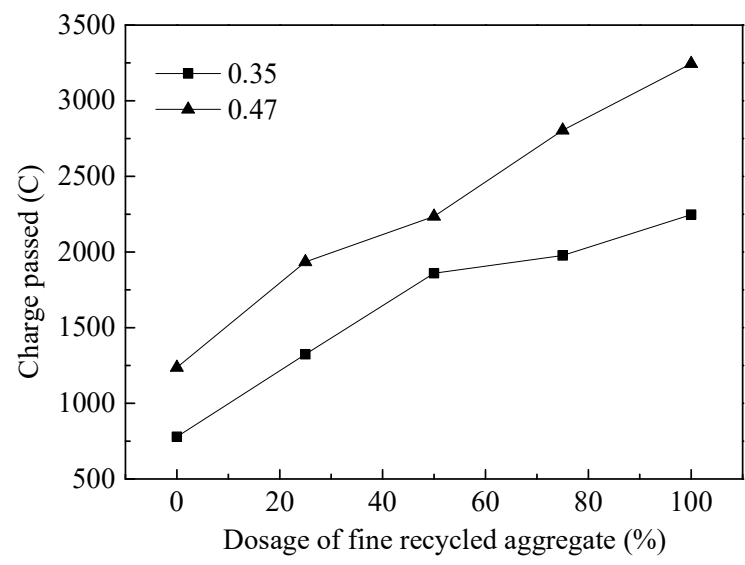

Figure 1. Effect of the dosage of fine recycled aggregate on the permeability of concrete. 
Table 7. Chloride ion penetrability based on charge passed.

\begin{tabular}{cc}
\hline Electric flux $(6 \mathrm{~h}, \mathrm{C})$ & Permeability \\
\hline$>4000$ & High \\
\hline $2000-4000$ & Moderate \\
\hline $1000-2000$ & Low \\
\hline $100-1000$ & Very low \\
\hline$<100$ & Negligible \\
\hline
\end{tabular}

\subsection{Carbonation Resistance}

The effect of the dosage of fine recycled aggregate on the carbonation depth of concrete is described in Figure 2. Generally, concrete with higher water to cement ratio has more pores, and $\mathrm{CO}_{2}$ could get into concrete much easier through these pores. Consequently, the carbonation depth increased with the increasing of water to cement ratio for all test age. The carbonation depth also increased with the increasing of the test age and the replacement level of recycled clay brick. The porous recycled clay brick may carbonate considerably faster than the concrete with natural aggregate, causing a increase of the carbonation depth which was shown in Figure 3.
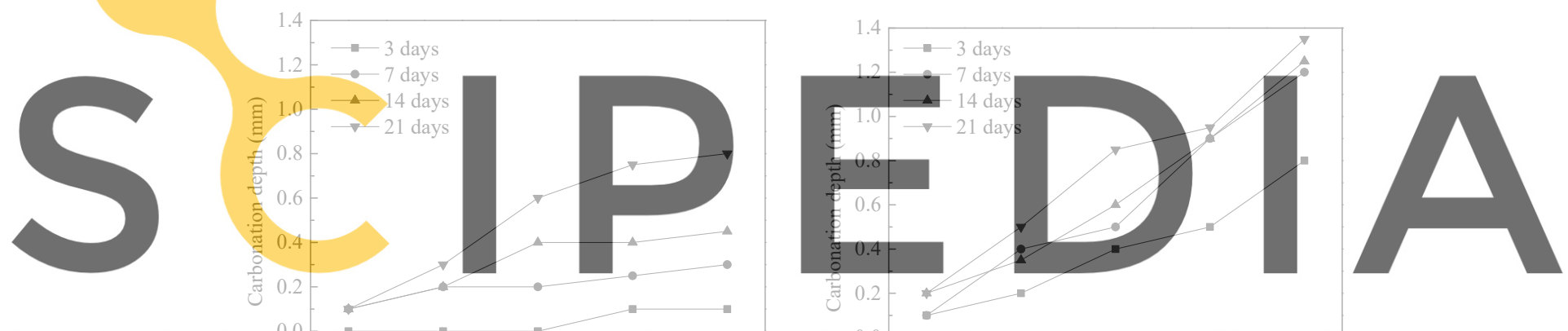

Register for free at https//Www.scipedia.com to download the version without the watermark Dosage of fine recycled aggregate $(\%)$

(a) $W / C=0.35$.

Dosage of fine recycled aggregate $(\%)$

(b) $W / C=0.47$.

Figure 2. Effect of the dosage of fine recycled aggregate on the carbonation depth of concrete.

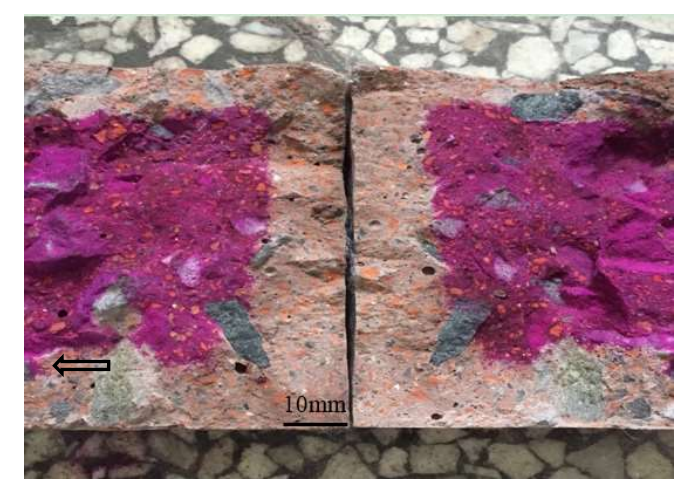

Figure 3. Surface of split concrete cube with the replacement level of $100 \%$ used in the carbonation test after being sprayed with phenolphthalein at 21 days $(W / C=0.47)$. 


\section{Conclusions}

Based on the above experimental results, some conclusions could be drawn below:

- Both the compressive strength and the flexural strength decreased with the increasing of the replacement percent of recycled clay brick.

- The impermeability of concrete decreased with the increasing of the replacement percent of recycled clay brick. But the permeability of concrete with the water to cement ratio of 0.35 was still kept at "Low" level when the replacement percent was less than or equal to $75 \%$.

- The carbonation resistance of concrete using recycled clay bricks as fine aggregate was degraded.

\section{Acknowledgment}

The investigation and results reported in this paper are supported by Technology Program (Technology-2014-04002) from Guang Dong Province Department of Transportation, Technology Program (JCYJ20150831200925298) from Science and Technology Innovation Committee of Shen Zhen, and Technology Program (JX2016CG-F014) from Housing and Construction Bureau of Shen Zhen.

\section{ORCID}

Wencui Yang: https://orcid.org/0000-0002-5006-9888

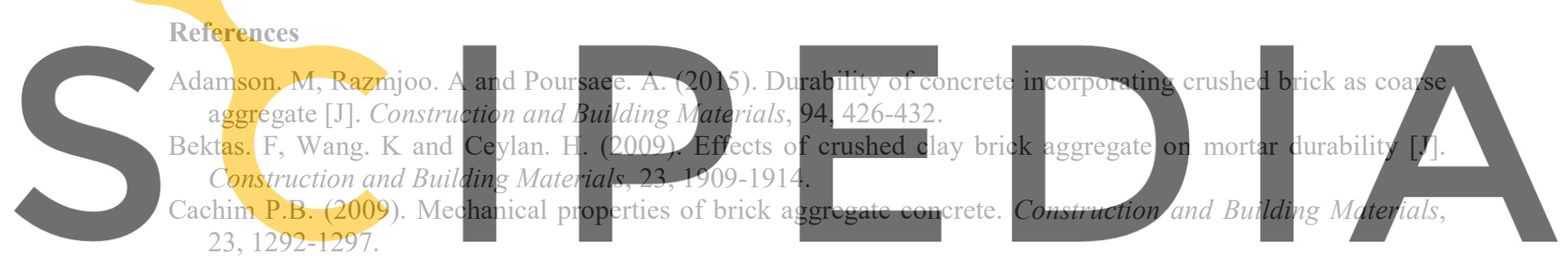

Crowther P. (2000). Building deconstruction in Australia. Overview of Deconstruction in Selected Countries,

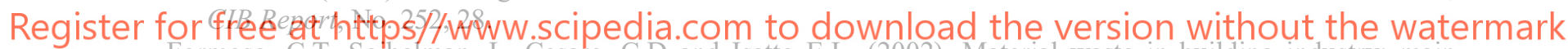

Formoso. C.T, Solbelman. L, Cesare. C.D and Isatto E.L. (2002). Material waste in building industry: main causes and prevention [J]. Journal of Construction Engineering and Management, 128, 316-325.

Khalaf. F.Mi. (2005). Properties of new and recycied clay brick aggregates for use in concrete [J]. Journal of Materials in Civil Engineering, 17, 456-464.

Khalaf F.M. (2006). Using crushed clay brick as coarse aggregate in concrete [J]. Journal of Materials in Civil Engineering, 18, 518-526.

Poon. C.S and Chan. D. (2006). Feasible use of recycled concrete aggregates and crushed clay brick as unbound road sub-base. Construction and Building Materials, 20, 578-585.

Schackow. A, Stringari. D and Senff. L. et al. (2015). Influence of fired clay brick waste additions on the durability of mortars [J]. Cement and Concrete Composites, 62, 82-89.

Vieira. T, Alves. A and Brito. J. de, et al. (2016). Durability-related performance of concrete containing fine recycled aggregates from crushed bricks and sanitary ware [J]. Materials and Design, 90, 767-776.

Zong Lan, Fei Zhengyue and Zhang Shiping. (2014). Permeability of recycled aggregate concrete containing fly ash and clay brick waste [J]. Journal of Cleaner Production, 70, 175-182. 